\title{
ANALISA METODE AHP (ANALYTIC HIERARCHY PROCESS) DAN TOPSIS (TECHNIQUE FOR ORDER REFERENCE BY SIMILIARITY TO IDEAL SOLUTION) UNTUK SISTEM PENDUKUNG KEPUTUSAN E-RECRUITMEN PENYIAR RADIO XYZ
}

\author{
Hani Zulfia ${ }^{1}$, Febriana Santi Wahyuni ${ }^{2}$ \\ ${ }^{1,2)}$ Teknik Informatika, Institut Teknologi Nasional Malang \\ hani.zulfia@gmail.com
}

\begin{abstract}
ABSTRAK
Sistem Pendukung Keputusan (SPK) mempunyai beberapa metode untuk menyelesaikan permasalahan dalam proses pengambilan keputusan yang dibuat oleh pembuat keputusan. Salah satu metode yang digunakan pada sistem pengambilan keputusan ialah metode AHP (Analytical Hierarchy Process) dan TOPSIS (Technique for Order of Preference by Similarity to Ideal Solution). Pada proses penentuan calon penyiar radio tidaklah mudah, karena dalam proses e-recruitmen calon penyiar radio memiliki kriteria-kriteria tertentu yang perlu diperhatikan. Permasalahan muncul pada ketidaktepatan tim penilai dalam memberikan penilaian kepada calon penyiar radio. Sehingga penilaian yang diberikan masih bersifat tidak pasti dan subjektif. Kesalahan dalam pemilihan calon penyiar radio akan memberikan dampak bagi perusahaan /organisasi. Kriteria-kriteria penentuan calon penyiar radio berdasarkan pada pendekatan kualitatif dan kuantitatif, dengan menggunakan metode AHP dan TOPSIS untuk pembobotan kriteria dan uji konsistensi terhadap matriks perbandingan berpasangan dan perangkingan untuk menentukan alternatif yang terpilih dengan menggunakan bobot kriteria tersebut. Perbandingan antara metode AHP dan TOPSIS adalah untuk mengetahui apakah hasil yang diberikan dari perbandingan kedua metode tersebut sama atau mengalami hasil yang berbeda, serta mengetahui metode manakah yang mampu memberikan informasi yang lebih akurat dalam proses e-recruitmen penyiar radio XYZ.
\end{abstract}

Keyword : SPK, AHP, TOPSIS, E-recruitmen

\section{PENDAHULUAN}

Radio diartikan sebagai media massa tercepat dan mampu dijangkau oleh khalayak ramai (Huffman, 2001: 73). Radio merupakan alat komunikasi paling tua sebelum bermunculan alat telekomunikasi canggih yang ada pada saat ini. Radio adalah alat teknologi yang berfungsi untuk mengirimkan sinyal dengan cara melakukan modulasi dan dapat juga dengan cara menggunakan radiasi yang berasal dari gelombang elektromagnetik radio. Penyiar radio sebagai salah satu unsur penting dalam suatu radio sangat menentukan penyampaian informasi maupun hiburan kepada pendengar. Untuk mendapatkan kualitas penyiar radio yang baik maka dibutuhkan seleksi calon penyiar radio. Seleksi calon penyiar radio dilakukan untuk mencari calon penyiar radio mana yang baik dan paling sesuai dengan persyaratan yang diperlukan oleh perusahaan.

Dalam proses pemilihan penyiar radio $\mathrm{XYZ}$ masih dilakukan dengan penghitungan manual, yaitu melakukan penilain terhadap calon penyiar radio secara subjektif. Permasalahan muncul pada ketidaktepatan tim penilai dalam memberikan penilaian kepada calon penyiar radio. Sehingga penilaian yang diberikan masih bersifat tidak pasti. Maka seorang program director dalam perhitungan penilaian terhadap kriteria harus benar-benar relevan, karena pada dasarnya akan berpengaruh pada hasil akhir. Kesalahan dalam memilih calon penyiar radio akan memberikan dampak bagi perusahaan atau organisasi, efisiensi, produktivitas, dan dapat merusak moral para pendengar.

Penentuan calon penyiar radio berdasarkan pada pendekatan kualitatif dan kuantitatif. Metode yang digunakan adalah metode Analitycal Hierarchy Process (AHP) dan TOPSIS (Technique for Order of Preference by Similarity to Ideal Solution). Prinsip kerja AHP yaitu penyederhanaan suatu persoalan kompleks yang tidak terstruktur menjadi bagian-bagiannya, serta menata dalam suatu hirarki. TOPSIS adalah salah satu metode pengambilan keputusan multikriteria yang pertama kali diperkenalkan oleh Yoon dan Hwang pada tahun 1981. Metode ini merupakan salah satu metode yang banyak digunakan untuk menyelesaikan pengambilan keputusan secara praktis. TOPSIS memiliki konsep dimana alternatif yang terpilih merupakan alternatif terbaik yang memiliki jarak terpendek dari solusi ideal positif dan jarak terjauh dari solusi ideal negatif. Penentuan calon penyiar radio XYZ dengan membandingkan antara dua metode AHP dan TOPSIS untuk memperoleh hasil calon penyiar radio yang sesuai dengan kriteria.

Berdasarkan latar belakang yang telah diberikan, maka penulis bermaksud melakukan suatu penelitian yang berjudul "Analisa Metode AHP (Analytic Hierarchy Process) dan TOPSIS (Technique for Order Reference by Similiarity to Ideal Solution) untuk Sistem

Pendukung Keputusan E-recruitment Penyiar Radio XYZ”. 


\section{TINJAUAN PUSTAKA \\ 2.1 Penyiar Radio}

Radio diartikan sebagai media massa tercepat dan mampu dijangkau oleh khalayak ramai (Huffman, 2001: 73). Dalam bahasa Inggris, penyiar disebut announcer (arti harfiyah: orang yang mengumumkan). Menurut Kamus Besar Bahasa Indonesia (KBBI), penyiar adalah orang yang menyiarkan atau penyeru pada radio.

Penyiar radio adalah seorang yang bertugas menyebarkan (syiar) suatu atau lebih informasi yang terjamin akurasinya dengan menggunakan radio dengan tujuan untuk diketahui oleh pendengarnya, dilaksanakan, dituruti, dan dipahami (Anonymous. 2015)

\subsection{E-Recruitment}

E-Recruitment adalah penggunaan internet untuk menarik karyawan yang potensial ke dalam suatu organisasi, termasuk di dalamnya adalah penggunaan dari situs perusahaan itu sendiri, organisasi dan penggunaan papan pengumuman lowongan pekerjaan komersial secara online (Parry, 2006).

\subsection{Sistem Pendukung Keputusan (SPK)}

Sistem Pendukung Keputusan (SPK) atau Decision Support System (DSS) didefinisikan sebagai sistem komputer yang mampu memberikan kemampuan baik kemampuan pemecahan masalah maupun kemampuan pengkomunikasian untuk masalah semi terstruktur. Secara khusus, DSS didefinisikan sebagai sebuah sistem yang mendukung kerja seorang manager maupun sekelompok manager dalam memecahkan masalah semi terstruktur dengan cara memberikan informasi ataupun usulan menuju pada keputusan tertentu (Indrajit, 2015).

\subsection{AHP (Analytic Hierarchy Process)}

AHP yang dikembangkan oleh Thomas L. Saaty,1994. dapat memecahkan masalah yang kompleks dimana aspek atau kriteria yang diambil cukup banyak. Juga komplekstias ini disebabkan oleh struktur masalah yang belum jelas, ketidakpastian persepsi pengambilan.

Prosedur Metode AHP (Analytical Hierarchy Process) sebagai berikut:

1. Mendifinisikan masalah dan menentukan solusi yang dinginkan.

2. Menentukan Prioritas Elemen.

a. Membuat perbandingan pasanangan, yaitu membandingkan elemen secara berpasangan sesuai kriteria yang diberikan.

b. Matriks perbandingan berpasangan diisi menggunakan bilangan untuk merepresentasikan kepentingan relatif dari suatu elemen terhadap elemen lainnya.
3. Sintesis

Pertimbangan-pertimbangan terhadap perbandingan berpasangan disitesis untuk memperoleh keseluruhan prioritas. Hal-hal yang dilakukan dalam langkah ini adalah sebagai berikut:

a. Menjumlahkan nilai-niali dari setiap kolom pada matriks.

b. Membagi setiap nilai dari kolom dengan total kolom yang bersangkutan untuk memperoleh normalisasi matriks.

c. Menjumlahkan nilai-nilai dari setiap baris dan membaginya dengan jumlah elemen untuk mendapat nilai rata-rata.

4. Mengukur Konsistensi

Dalam pembuatan keputusan, penting untuk mengetahui seberapa baik konsistensi yang ada, karena dalam membuat keputusan tidak menginginkan keputusan berdasarkan pertimbangan dengan konsistensi yang rendah. Hal-hal yang dilakukan untuk langkah ini adalah sebagai berikut:

a. Mengalikan setiap nilai pada kolom pertama dengan prioritas relatif elemen pertama, nilai pada kolom kedua dengan prioritas relatif elemen kedua dan sampai dengan banyaknya nilai.

b. Menjumlahkan setiap baris.

c. Hasil dari penjumlahan setiap baris dibagi dengan elemen prioritas relatif yang bersangkutan.

d. Menjumlahkan hasil dari pembagian dengan banyaknya elemen yang ada, maka hasilnya disebut dengan $\lambda$ maks.

5. Hitung Consistency Index (CI) dengan rumus sebagai berikut:

$$
C I=\frac{\lambda \text { Maksimum }-n}{n-1}
$$

Dimana $n=$ Banyaknya Elemen.

6. Hitung Rasio Konsistensi/Consistency Ratio (CR) dengan rumus sebagai berikut: $\frac{C R}{C I}$

Dimana:

$\mathrm{CR}=$ Consistency Ratio

CI = Consistency Index

IR = Index Random Consistency

7. Memeriksa konsistensi hierarki. Jika nilai yang didapat lebih dari 10\%, maka penialain data judgment hars diperbaiaki. Namun, apabila Rasio Konsistensi (CI/CR) kurang atau sama dengan 0,1 , maka hasil perhitungan tersebut benar (Kusrini,2007.). Dimana $\quad R I=$ Random Index yang nilainya dapat dilihat pada Tabel 1 di bawah ini:

Copyright (c) 2018 Jurnal Mnemonic 
Table 1 Daftar Nilai $R I$

\begin{tabular}{|c|c|c|c|}
\hline $\begin{array}{c}\text { Ukuran } \\
\text { Matriks }\end{array}$ & Nilai IR & $\begin{array}{c}\text { Ukuran } \\
\text { Matriks }\end{array}$ & Nilai IR \\
\hline 1,2 & 0.00 & 9 & 1.45 \\
\hline 3 & 0.58 & 10 & 1.49 \\
\hline 4 & 0.90 & 11 & 1.51 \\
\hline 5 & 1.12 & 12 & 1.48 \\
\hline 6 & 1.24 & 13 & 1.56 \\
\hline 7 & 1.32 & 14 & 1.57 \\
\hline 8 & 1.41 & 15 & 1.59 \\
\hline
\end{tabular}

2.5 TOPSIS (Technique for Order Reference by Similiarity to Ideal Solution)

Technique for Order Preference by Similarity to Ideal Solution atau (TOPSIS) didasarkan pada konsep dimana alternatif terbaik tidak hanya memiliki jarak terpendek dari solusi ideal positif, namun juga memiliki jarak terpanjang dari solusi ideal negatif (Hwang dan Yoon, 1981). Dalam Metode TOPSIS tidak terdapat batasan mengenai jumlah atribut dan alternatif yang digunakan, sehingga dapat digunakan untuk menyelesaikan suatu kasus yang memiliki atribut kuantitatif dengan lebih efisien (Rao, 2004). Dalam penelitian ini metode TOPSIS digunakan untuk melakukan perankingan terhadap variabel yang ada.

\section{METODE PENELITIAN}

\subsection{Tahapan Penelitian}

Metode penelitian dapat digambarkan bentuk diagram alur penelitian seperti pada Gambar 2 sebagai berikut:

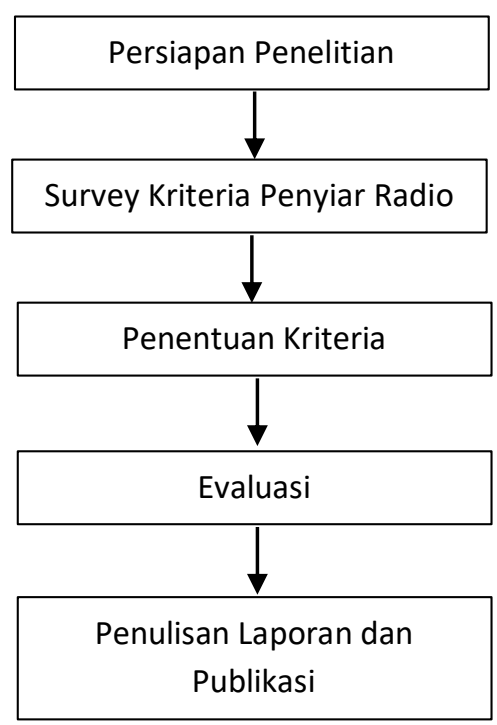

Gambar 1 Alur Penelitian
Adapun tahapan-tahapan penelitian yang akan dilakukan sebagai berikut:

1. Pesiapan penelitian

Pada tahap persiapan penelitian, dilakukan survei pustaka survei, materi, dan informasi tentang data - data terkait yang diutuhkan untuk kebutuhan fungsionalias

2. Survey kriteria penyiar radio

Pada tahapan ini dilakukan survey kriteriakriteria apasaja yang diperlukan.

3. Penentuan kriteria

Pada tahap perancangan ini dimulailah merancang algoritma sistem sesuai dengan kebutuhan fungsionalitas yang telah dilakukan survei pada proses persiapan penelitian.

4. Evaluasi

Tahapan evaluasi perancangan kebutuhan fungsional dilakukan dengan cara melakukan pengujian fungsionalitas agar mengetahui kinerja sistem dan apakah metode yang digunakan telah sesuaiatau tidak.

5. Penulisan laporan dan Publikasi

\subsection{Analisa Kebutuhan}

Kebutuhan dibagi menjadi dua, yaitu kebutuhan fungsional dan kebutuhan non fungsional, diuraikan sebagai berikut :

\subsection{Kebutuhan Fungsional}

Tahapan ini diawali dengan mengenal dan menganalisa kebutuhan. Hasil analisis spesifikasi perangkat lunak dilanjutkan dengan memetakan struktur fungsi komponen sehingga dapat disimpulkan beberapa solusi pemecahan masalah.

Dalam tahap ini konsep rancangan aplikasi Sistem Pendukung Keputusan adalah:

1. Menggunakan metode Analitycal Hierarchy Process (AHP) dan TOPSIS dalam menentukan kriteria dan sub kriteria calon penyiar baru.

2. Perbandingan proses menggunakan metode AHP dan TOPSIS, dalam menghitung proses penilaian kriteria dan sub kriteria dari masing-masing alternatif calon penyiar.

\subsubsection{Kebutuhan Non Fungsional}

Adapaun kebutuhan non fungsional yang digunakan dalam pelaksanaan penelitian ini adalah sebagai berikut :

Perhitungan manual

\section{HASIL DAN PEMBAHASAN}

\section{A. Perhitungan AHP}

Pengujian perhitungan merupakan suatu pengujian dari kriteria dan subkriteria yang ada sesuai dengan implementasi layout dan diuji berdasarkan nilai pada aplikasi pendukung keputusan yang telah dibuat. 


\section{a. Perhitungan Kriteria}

Matrik perbandingan berpasangan ini adalah langkah pertama pada proses AHP. Pada tahap ini dilakukan penilaian perbandingan antara satu kriteria dengan kriteria yang lain. Cara pengisian elemen matrik pada tabel :

1. Elemen $\mathrm{a}[\mathrm{i}, \mathrm{i}]=1$ dimana $\mathrm{i}=1,2, \ldots, \mathrm{n}(\mathrm{n}=4)$.

2. Elemen matriks segitiga atas sebagai input.

3. Elemen matriks segitiga bawah mempunyai rumus $a[j, i]=1 / a[i, j]$ untuk $i \neq j$.

Tabel 2.

Hasil penilaian kriteria yaitu seperti pada

Table 2 Matrik Perbandingan Berpasangan Kriteria

\begin{tabular}{|l|c|c|c|c|c|}
\hline & $\begin{array}{c}\text { Pengalaman } \\
\text { Broadcasting }\end{array}$ & $\begin{array}{c}\text { Penguasaan } \\
\text { Bahasa }\end{array}$ & Intonasi & Artikulasi & TPA \\
\hline $\begin{array}{l}\text { Pengalaman } \\
\text { Broadcasting }\end{array}$ & 1 & 3 & 3 & 3 & 4 \\
\hline $\begin{array}{l}\text { Penguasaan } \\
\text { Bahasa }\end{array}$ & 0,333333333 & 1 & 2 & 2 & 2 \\
\hline Intonasi & 0,333333333 & 0,5 & 1 & 2 & 2 \\
\hline Artikulasi & 0,333333333 & 0,5 & 0,5 & 1 & 3 \\
\hline TPA & 0,25 & 0,5 & 0,5 & 0,3333333333 & 1 \\
\hline Jumlah & 2,25 & 5,5 & 7 & 8,333333333 & 12 \\
\hline
\end{tabular}

Angka 1 pada kolom Pengalaman Broadcasting baris Pengalaman Broadcasting menggambarkan tingkat kepentingan yang sama antara Pengalaman Broadcasting dengan Pengalaman Broadcasting, sedangkan angka 3 pada kolom Penguasaan Bahasa baris Pengalaman Broadcasting menunjukkan bahwa Penguasaan Bahasa lebih penting dibandingkan Pengalaman Broadcasting.

Angka 0,3333333 pada kolom Pengalaman Broadcasting baris Penguasaan Bahasa merupakan hasil perhitungan angka 1 pada baris dan kolom Pengalaman Broadcasting baris Pengalaman Broadcasting dibangi dengan angka 3 pada kolom Penguasaan Bahasa baris Pengalaman Broadcasting. Sedangkan angka yang lain diperoleh dengan cara yang sama.

Matrik nilai prioritas adalah langkah kedua pada proses AHP seperti pada Tabel 3.

Table 3 Matrik Nilai Prioritas Kriteria

\begin{tabular}{|l|c|c|c|c|c|c|c|}
\hline & $\begin{array}{c}\text { Pengalaman } \\
\text { Broadcasting }\end{array}$ & $\begin{array}{c}\text { Penguasaan } \\
\text { Bahasa }\end{array}$ & Intonasi & Artikulasi & TPA & Jumlah & Prioritas \\
\hline $\begin{array}{l}\text { Pengalaman } \\
\text { Broadcasting }\end{array}$ & 0,4444444444 & 0,5454545455 & 0,428571429 & 0,36 & 0,3333333333 & 2,111803752 & 0,42236075 \\
\hline $\begin{array}{l}\text { Penguasaan } \\
\text { Bahasa }\end{array}$ & 0,1481448148 & 0,181818182 & 0,2857142286 & 0,24 & 0,1666666667 & 1,022347282 & 0,204469456 \\
\hline Intonasi & 0,1481448148 & 0,090909091 & 0,142857143 & 0,24 & 0,166666667 & 0,788581049 & 0,15771621 \\
\hline Artikulasi & 0,148148148 & 0,090909091 & 0,071425571 & 0,12 & 0,25 & 0,68048581 & 0,136097162 \\
\hline TPA & 0,111111111 & 0,090909091 & 0,071428571 & 0,04 & 0,0833333333 & 0,396782107 & 0,0793564421 \\
\hline
\end{tabular}

Perhitungan selanjutnya yaitu membuat matrik penjumlahan setiap baris kriteria. Matrik ini dibuat dengan mengalikan nilai prioritas pada tabel matrik nilai kriteria dengan matrik perbandingan berpasangan seperti pada Tabel 4 .
Table 4 Matrik Penjumlahan Setiap Baris Kriteria

\begin{tabular}{|l|c|c|c|c|c|c|}
\hline & $\begin{array}{c}\text { Pengalaman } \\
\text { Broadcasting }\end{array}$ & $\begin{array}{c}\text { Penguasaan } \\
\text { Bahasa }\end{array}$ & Intonasi & Artikulasi & TPA & Jumlah \\
\hline $\begin{array}{l}\text { Pengalaman } \\
\text { Broadcasting }\end{array}$ & 0,42236075 & 0,613408369 & 0,473148629 & 0,408291486 & 0,317425685 & 2,234654921 \\
\hline $\begin{array}{l}\text { Penguasaan } \\
\text { Bahasa }\end{array}$ & 0,140786917 & 0,204469456 & 0,315432419 & 0,272194324 & 0,158712843 & 1,09159596 \\
\hline Intonasi & 0,140786917 & 0,102234728 & 0,15771621 & 0,272194324 & 0,158712843 & 0,831645022 \\
\hline Artikulasi & 0,140786917 & 0,102234728 & 0,078858105 & 0,136097162 & 0,238069264 & 0,696046176 \\
\hline TPA & 0,105590188 & 0,102234728 & 0,078858105 & 0,045365721 & 0,079356421 & 0,411405163 \\
\hline
\end{tabular}

Selanjutnya adalah menentukan rasio konsistensi yang digunakan untuk memastikan bahwa nilai rasio konsistensi $(\mathrm{CR})<=0,1$ jika nilainya lebih besar dari 0,1 maka matrik perbandingan berpasangan perlu diperbaiki seperti pada Tabel 5.

Table 5 Perhitungan Rasio Konsistensi Kriteria

\begin{tabular}{|l|c|c|c|}
\hline & Jumlah & Prioritas & Hasil \\
\hline Pengalaman Broadcasting & 2,234634921 & 0,42236075 & 2,656995671 \\
\hline Penguasaan Bahasa & 1,09159596 & 0,204469456 & 1,296065416 \\
\hline Intonasi & 0,831645022 & 0,15771621 & 0,989361231 \\
\hline Artikulasi & 0,696046176 & 0,136097162 & 0,832143338 \\
\hline TPA & 0,411405163 & 0,079356421 & 0,490761584 \\
\hline Jumlah & \multicolumn{4}{|l|}{} & 6,265327241 \\
\hline
\end{tabular}

Pada Tabel 6 merupakan hasil perhitungan nilai konsistensi kriteria utama. Pada Tabel 7 tersebut dihitung nilai $\lambda$ maks, CI, CR dan konsistensinya. Pada Tabel 8 hasil pengolahan nilai akternatif

Table 6 Perhitungan Nilai Konsistensi Kriteria

\begin{tabular}{|l|c|}
\hline$\lambda($ MAKS $(J U M A L A H / N)$ & 0,531399134 \\
\hline CI $(\lambda$ MAKS $-\mathrm{N}) / \mathrm{N}$ & $-0,893720173$ \\
\hline CR $(\mathrm{CI} / \mathrm{RI})$ & $-0,79796444$ \\
\hline KONSISTEN? & Konsisten \\
\hline
\end{tabular}

Table 7 Matrik Nilai Prioritas Kriteria

\begin{tabular}{|c|c|c|c|c|c|c|}
\hline Altematif & $\begin{array}{c}\text { Pengalaman } \\
\text { Broadcasting }\end{array}$ & $\begin{array}{c}\text { Penguasaan } \\
\text { Bahasa }\end{array}$ & Intonasi & Artikulasi & TPA & Total \\
\hline A & 1,00 & 1,00 & 0,41 & 0,41 & 0,55 & 3,3741485270896 \\
\hline B & 0,43 & 0,41 & 1,00 & 1,00 & 1,00 & 3,8389774738704 \\
\hline C & 0,43 & 1,00 & 1,00 & 0,41 & 0,55 & 3,3905169651689 \\
\hline D & 0,43 & 1,00 & 1,00 & 1,00 & 1,00 & 4,4276729559748 \\
\hline E & 0,43 & 0,41 & 0,41 & 1,00 & 0,55 & 2,8018214830645 \\
\hline F & 0,43 & 0,41 & 0,41 & 0,41 & 0,55 & 2,21312600096 \\
\hline G & 1,00 & 0,41 & 1,00 & 1,00 & 0,55 & 3,9628440091941 \\
\hline H & 0,43 & 0,41 & 1,00 & 1,00 & 1,00 & 3,250281991766 \\
\hline I & 1,00 & 0,41 & 0,41 & 0,41 & 1,00 & 3,2339135536867 \\
\hline J & 0,43 & 0,41 & 0,41 & 0,41 & 0,55 & 2,8018214830645 \\
\hline
\end{tabular}

\section{b. Perhitungan TOPSIS}

Adapun langkah-langkah dalam perhitungan TOPSIS sebagai berikut:

1. Menentukan tabel kepentingan, yang menggambarkan mengenai prioritas kriteria dalam perhitungan, ditunjukkan pada Tabel 8 sebagai berikut.

Table 8 Kepentingan

\begin{tabular}{|c|c|}
\hline 1 & Sangat Rendah \\
\hline 2 & Rendah \\
\hline 3 & Cukup \\
\hline 4 & Tinggi \\
\hline 5 & Sangat Tinggi \\
\hline
\end{tabular}


2. Membuat tabel penilaian alternatif calon penyiar, pada Tabel 9 sebagai berikut.

Table 9 Penilaian Alternatif Calon Penyiar .

\begin{tabular}{|c|c|c|c|c|c|}
\hline Cost Benefit & Pengalaman & Penguasaan Bahasa & Intonasi & Artikulasi & TPA \\
\hline Kepentingan & 5 & 4 & 4 & 4 & 3 \\
\hline $\begin{array}{c}\text { Altematif } / \\
\text { kriteria }\end{array}$ & Pengalaman & Penguasaan Bahasa & Intonasi & Artikulasi & TPA \\
\hline A & 5 & 4 & 75 & 79 & 68 \\
\hline B & 4 & 3 & 85 & 80 & 90 \\
\hline C & 2 & 4 & 89 & 70 & 70 \\
\hline D & 3 & 4 & 89 & 80 & 87 \\
\hline E & 3 & 2 & 60 & 85 & 80 \\
\hline F & 2 & 2 & 69 & 70 & 80 \\
\hline G & 10 & 3 & 80 & 89 & 80 \\
\hline H & 3 & 2 & 70 & 86 & 90 \\
\hline I & 5 & 3 & 78 & 79 & 85 \\
\hline J & 3 & 3 & 85 & 70 & 68 \\
\hline & & 9,797958971 & 248,3183441 & 250,0479954 & 253,6572491 \\
\hline Pembagi & 14,49137675 & \multicolumn{5}{|l}{}
\end{tabular}

3. Membangun normalized decision matriks elemen $r_{i j}$ hasil dari normalisasi decision matrix R dengan metode Euclidean length of a vector

4. Membangun weighted normalized decision matrix dengan bobot $W=(w 1, w 2, \ldots ., w n)$. Ditunjukkan pada Tabel 10.

Table 10 Weighted Normalized Decision Matrix \begin{tabular}{|c|c|c|c|c|c|}
\hline A & 1,725163898 & 1,632993162 & 1,208126613 & 1,263757382 & 0,804234851 \\
\hline B & 1,380131119 & 1,224744871 & 1,369210162 & 1,279754311 & 1,06442848 \\
\hline C & 0,690065559 & 1,632993162 & 1,433643581 & 1,119785022 & 0,827888818 \\
\hline D & 1,035098339 & 1,632993162 & 1,433643581 & 1,279754311 & 1,02894753 \\
\hline E & 1,035098339 & 0,816496581 & 0,966501291 & 1,359738955 & 0,946158649 \\
\hline F & 0,690065559 & 0,816496581 & 1,111476484 & 1,119785022 & 0,946158649 \\
\hline G & 3,450327797 & 1,224744871 & 1,288668387 & 1,423726671 & 0,946158649 \\
\hline H & 1,035098339 & 0,816496581 & 1,127584839 & 1,375735884 & 1,06442848 \\
\hline I & 1,725163898 & 1,224744871 & 1,256451678 & 1,263757382 & 1,005293564 \\
\hline J & 1,035098339 & 1,224744871 & 1,369210162 & 1,119785022 & 0,804234851 \\
\hline
\end{tabular}

5. Menentukan solusi ideal positif dan solusi ideal negatif. Solusi ideal positif dinotasikan dengan A+ dan solusi ideal negatif dinotasikan dengan A-. Ditunjukkan pada Tabel 11.

Table 11 Solusi Ideal Positif (A+) Dan Solusi Ideal Negatif (A-)

\begin{tabular}{|l|l|l|l|l|l|} 
A+ & 0,690065559 & 0,816496581 & 0,966501291 & 1,119785022 & 0,804234851 \\
\hline
\end{tabular} \begin{tabular}{|l|l|l|l|l|l|}
\hline A- & 3,450327797 & 1,632993162 & 1,433643581 & 1,423726671 & 1,06442848 \\
\hline
\end{tabular}

6. Menghitung separasi, separation measure ini merupakan pengukuran jarak dari suatu alternatif ke solusi ideal positif dan solusi ideal negatif pada Tabel 12 sebagai berikut.

Table 12 Kedekatan Relatif Terhadap Solusi Ideal

\begin{tabular}{|c|c|c|c|}
\hline Alternatif/Kriteria & D + & D- & V \\
\hline A & 1,348038 & 1,766448 & 0,567172 \\
\hline B & 0,947799 & 2,115954 & 0,690641 \\
\hline C & 0,940983 & 2,787002 & 0,747589 \\
\hline D & 1,039241 & 2,419777 & 0,699556 \\
\hline E & 0,443585 & 2,595439 & 0,854037 \\
\hline F & 0,20288 & 2,914768 & 0,934925 \\
\hline G & 2,828786 & 0,449079 & 0,137004 \\
\hline H & 0,527453 & 2,568263 & 0,829618 \\
\hline I & 1,176146 & 1,789788 & 0,603448 \\
\hline J & 0,669245 & 2,482787 & 0,787678 \\
\hline
\end{tabular}

Alternatif terbaik adalah salah satu yang yang memiliki nilai tertinggi terhadap solusi ideal dan nilai terendah dengan solusi ideal negatif (Kurniasih, D. 2013. Dari hasil perhitungan, nilai tertinggi diperoleh pada kriteria $\mathrm{F}$ dengan nilai $\mathrm{V}$ sebesar 0,934925 .

\section{KESIMPULAN DAN SARAN \\ 5.1 Kesimpulan}

Berdasarkan hasil analisa metode AHP dan TOPSIS, maka kesimpulan yang diperoleh yaitu :

1. Pada hasil perhitungan AHP, alternatif D, C dan $G$ memiliki hasil tertinggi 4,4276729559748, 3,9628440091941, dan 3,9628440091941.

2. Pada hasil perhitungan TOPSIS alternatif F, E, dan $\mathrm{H}$ hasil tertinggi $0,934925,0,854037$, dan 0,829618

3. Pada hasil pengujian metode AHP dan TOPSIS adanya perbedaan hasil.

\subsection{Saran}

Adapun saran yang dapat diberikan untuk pengembangan selanjutnya adalah sebagai berikut:

1. Dikembangkan lagi dengan metode-metode yang lain sehingga didapat hasil yang lebih baik.

2. Perhitungan AHP dan TOPSIS diimplementasikan ke dalam sebuah sistem.

\section{DAFTAR PUSTAKA}

[1]. Anonymous. 2015 Universitas Sumatera Utara. (http://repository.usu.ac.id/bitstream /123456789/52362/4/Chapter\%20II.pdf)

[2]. Anonymous. 2015. Unikom.(http://elib.unikom .ac.id/files/disk1/677/jbptunikomppgdlivansyanif-33817-8-unikom_i-i.pdf)

[3]. Hwang dan Yoon. 1981. Multiple Attribute Decision Making, Lecture Notes in Economics and Mathematical System. 186

[4]. Huffman, A., Huffman Amber D., 2001. Method for determining the end of transmission in a software radio having multiple processors. U.S. Patent Application 09/939,347.

[5]. Indrajit, Richardus Eko. Decision Support System. Tersedia: (http://dosen.narotama.ac.id/ wpcontent/uploads/2012/01/Decision-Support -System.pdf)

[6]. Kosasi, Sandy. 2002. Sistem Penunjang Keputusan (Decision Support System). Pontianak.

[7]. Kusrini. 2007. Konsep dan Aplikasi Sistem Pendukung Keputusan. Yogayakarta:

[8]. Nur Shodiq, R.I.Z.K.I., 2015. Strategi Radio Gema Surya Fm Dalam Melestarikan Seni Instrumental Jawa Di Ponorogo (Doctoral dissertation, Universitas Muhammadiyah Ponorogo). 
[9]. Parry, E. 2006. Drivers of the Adoption of Online Recruitment: An Analysis Using Diffusion of Innovation Theory. Cranfield School of Management, 1 -13.

[10]. Rao. 2004. Evaluation of Metal Stamping Layout Using a Combained Multiple Attribute Decision Making Method, IE (I) Journal-PR.

[11]. Saaty, Thomas, L., 1994. The Analytical Hierarchy Process. Yogyakarta: Ardana Media.

[12]. Volk, M. 2010. Ralf Seppelthow can we make Progress with decision support systems in landscape and river basin management? Lessons learned from a comparative analysis of four different decision support systems, Environmental Management 46,pp.834-849.

[13]. Yoon, K.P. and Hwang, C.L., 1995. Multiple attri bute decision making: an introduction (Vol.104). Sage publications. 